gestive of the 3 conditions reported as being a cause of progressive subglottic narrowing in adults. ${ }^{2}$ Most reported cases of perichondritis with subglottic involvement have had associated inflammation of the nasal cartilages. Sarcoidosis is a rare disorder in children and usually there is generalised lymphadenopathy or changes on the chest radiograph. A diagnosis of Wegener's granulomatosis was entertained in Case 4 but there were no other features of the disorder although the boy did have granulomatous panniculitis. The relationship of this and of Hashimoto's disease in Case 3 to the subglottic lesion is unclear. There is a single case report $^{8}$ of an adult with progressive non-traumatic subglottic narrowing but this did not respond to steroids.

It is important that paediatricians be aware of this disorder. These children all had findings typical of laryngeal obstruction although for months they were thought to have asthma, and were dangerously obstructed by the time they were finally diagnosed. The disorder appears to be very sensitive to corticosteroids and these should be used in patients suspected of having a similar condition before resorting to major surgery.

Dr Hey was supported by the Harley Williams Travelling Fellowship of the British Chest Heart and Stroke Association while he was a visiting paediatrician in Melbourne.
References

1 Holinger P H, Kutnick S L, Schild J A, Holinger L D. Subglottic stenosis in infants and children. Ann Otol Rhinol Laryngol 1976; 85: 591-9.

2 Djalilian M, McDonald T J, Devine K D, Weiland L $\mathbf{H}$. Nontraumatic, non-neoplastic subglottic stenosis. Ann Otol Rhinol Laryngol 1975; 84: 757-63.

3 Weisman R A, Canalis R F, Powell W J. Laryngeal sarcoidosis with airway obstruction. Ann Otol Rhinol Laryngol 1980; 89: 58-61.

4 McDonald T J, DeRemee R A, Kern E B, Harrison E G. Nasal manifestations of Wegener's granulomatosis. Laryngoscope 1974; 84: 2101-12.

5 Sharma D B, Lahori U C. An unusual type of subacute subglottic narrowing causing prolonged and persistent upper airway obstruction. Indian $J$ Pediatr 1976; 43: 18-20.

6 Williams H E, Phelan P D, Stocks J G, Wood H. Haemangioma of the larynx in infants. Aust Paediatr $J$ $1969 ; 5: 149-54$.

7 Holinger P H, Slaughter D P, Novak F J, III. Unusual tumors obstructing the lower respiratory tract of infants and children. Trans Am Acad Ophthamol Otolaryngol $1950 ; 54: 223-4$.

8 Diamant H, Schiratzki H. Chronic fibrosis of the subglottic space and possibly the paranasal sinuses and tympanic cavities. Laryngoscope 1969; 79: 355-67.

Correspondence to Prof P D Phelan, Department of Thoracic Medicine, Royal Children's Hospital, Melbourne 3052, Australia.

No reprints available.

Received 2 August 1982

\title{
Spontaneous hypothermia in a young boy
}

\author{
B K SANDHU, M BOMMEN, AND C G D BROOK
}

Middlesex Hospital, London

SUMMARY A 13-year-old boy who maintains his body temperature between 33 and $35^{\circ} \mathrm{C}$ was investigated. Tests of peripheral and central thermoregulatory function did not show a specific abnormality, except for some generalised hypothalamic dysfunction of unknown aetiology. He responded appropriately when his temperature was altered from its usual low level. His temperature regulatory mechanisms appeared to be set at a temperature lower than is normal.

Hypothermia is defined as a rectal or body-core temperature below $35^{\circ} \mathrm{C}$. Accidental hypothermia is common-especially in the elderly 1 - but spontaneous hypothermia is rare-particularly in young adults-if hypothyroidism is excluded. Several cases have been reported during the last 50 years, ${ }^{2-5}$ but studies of underlying central and peripheral thermoregulatory function are few, especially in children. We report results of investigations on a hypothermic 13-year-old boy.

\section{Case history}

The boy was born in India, a term normal delivery, birthweight $3.2 \mathrm{~kg}$. He developed jaundice in the first 3 days of life which persisted for about 4 weeks. No blood tests were done or treatment given. He breast fed well and there were no other illnesses. He sat at age 8 months and walked at 19 months. He can communicate and read in his native language 
and perform daily chores but is thought by his family to be slow. He speaks only a few words of English. The parents and 6 siblings are healthy. He came to the UK in September 1980 and presented 2 months later with a history of withdrawal and slowness, particularly since his arrival here.

On examination his oral temperature was $33.8^{\circ} \mathrm{C}$, pulse rate $72 / \mathrm{min}$, and regular; heart sounds normal, blood pressure $110 / 60 \mathrm{mmHg}$, chest clear, abdomen normal. Head circumference was $52 \cdot 1 \mathrm{~cm}$, cranial nerve examination and fundoscopy were normal. It was possible to elicit a weak triceps reflex but other reflexes could not be elicited. Plantar reflexes were flexor and sensation to temperature (cold and warm), touch, pressure, pain, and position appeared normal. There was no loss of muscle power and autonomic responses appeared normal. Response to Valsalva's manoeuvre was normal and there was no hypotension on tilting. Weight and height were appropriate for age and parental sizes. He was thought initially to be myxoedematous but thyroid function tests gave normal results. He was therefore, further investigated and observed.

Investigations. The following investigations were normal: blood count, urea, and electrolytes, erythrocyte sedimentation rate, liver function tests, blood sugar, creatine phosphokinase, serum cholesterol, triglyceride, glucagon, autoantibody screen, immunoglobulins, serum thyroxine (156 nmol/l), tri-iodothyronine $(2.2 \mathrm{pmol} / \mathrm{l})$; skull and chest $x$-ray films, electrocardiogram, Mantoux, Wassermann reaction, computerised tomography scan of head. Electroencephalogram showed nonspecific slow wave changes; electromyogram showed normal conduction velocity but a small sural sensory action potential. Examination of the cerebrospinal fluid showed no cells and a protein concentration of $0.54 \mathrm{~g} / 1$; no evidence of virus infection was found. Serology was negative for influenza, mumps, measles, adenovirus, cyto- megalovirus, herpes, psittacosis, $\mathrm{Q}$ fever, and mycoplasma. There was no specific rubella IgM antibody and toxoplasma dye test was normal.

A combined insulin tolerance, thyroid-releasing hormone, luteinising hormone-releasing hormone test was carried out to test hypothalamo-pituitary function. Hypoglycaemia produced a poor and late response to adrenocorticotrophic hormone, which was reflected in a poor cortisol rise. The thyroidstimulating hormone response to thryoid-releasing hormone was inadequate and the prolactin response was rather flat. The gonadotrophin responses and diurnal variation of the hormones were normal. A synacthen test showed a normal adrenal response to injected adrenocorticotrophic hormone, serum cortisol rising in 30 minutes from 212 to $800 \mathrm{nmol} / \mathrm{l}$.

Diurnal urine excretion and a water deprivation test were normal. Muscle biopsy was histologically normal, and the mitochondria were normal in structure, numbers, and enzyme function.

In the ambient temperature of the hospital ward $\left(21-22^{\circ} \mathrm{C}\right)$ his oral and rectal temperature remained between 33 and $35^{\circ} \mathrm{C}$.

In response to cooling (Table 1) he was able to shiver and his basal metabolic rate rose. Basal metabolic rate was assessed by the open circuit method of indirect calorimetry, using a Douglas bag. During the same period the temperature of a control patient fell by $0.4^{\circ} \mathrm{C}$; she shivered more and appeared to be more uncomfortable than the patient. In response to warming (Table 2) he started feeling uncomfortable before the control patient and this discomfort increased as the temperature rose. At $37.3^{\circ} \mathrm{C}$ he became agitated and uncooperative whereas the control experienced only mild discomfort although her temperature rose to $37 \cdot 4^{\circ} \mathrm{C}$. The patient's basal metabolic rate increased only slightly and he did not show the usual correlation between respiration rate, pulse rate, and body temperature. No formal pyrogen test was done but his temperature rose to $35 \cdot 3^{\circ} \mathrm{C}$ during a common cold.

Table 1 Effect of cooling

\begin{tabular}{|c|c|c|c|c|c|c|c|}
\hline \multirow{2}{*}{$\begin{array}{l}\text { Time } \\
\text { (hours) }\end{array}$} & \multicolumn{3}{|c|}{ Temperature $\left({ }^{\circ} \mathrm{C}\right)$} & \multirow{2}{*}{$\begin{array}{l}\text { Heart rate } \\
(\text { per minute })\end{array}$} & \multirow{2}{*}{$\begin{array}{l}\text { Respiratory } \\
\text { rate } \\
\text { (per minute) }\end{array}$} & \multirow[t]{2}{*}{ Comments } & \multirow{2}{*}{$\begin{array}{l}\text { Basal metabolic rate } \\
\left(K J / m^{2} \text { per hour }\right)\end{array}$} \\
\hline & Room & Skin & Oral & & & & \\
\hline 1110 & 23 & 29 & $33 \cdot 6$ & 58 & 11 & Resting & 253 \\
\hline 1140 & 10 & $26 \cdot 5$ & $33 \cdot 6$ & 60 & 12 & Complains of feeling cold. Control $37^{\circ} \mathrm{C}$ & \\
\hline 1200 & 10 & 23 & $33 \cdot 2$ & 70 & 12 & Shivering, goose pimples & \\
\hline 1230 & 10 & $21 \cdot 8$ & 32 & 58 & 12 & Occasional ectopic beats & 236 \\
\hline 1250 & 10 & $21 \cdot 0$ & $31 \cdot 8$ & 48 & 12 & No more ectopic beats. Control $36 \cdot 8^{\circ}$ & \\
\hline 1310 & 10 & $21 \cdot 0$ & $30 \cdot 6$ & 44 & 12 & Shivering less & 324 \\
\hline 1325 & 10 & $20 \cdot 5$ & 31 & 42 & 15 & $\begin{array}{l}\text { Alert, notices nurses looking through window. } \\
\text { Feels cold and hungry. Control } 36 \cdot 6^{\circ}\end{array}$ & 426 \\
\hline 1340 & 10 & 20 & 30 & 42 & 12 & & \\
\hline
\end{tabular}


Table 2 Effect of warming

\begin{tabular}{|c|c|c|c|c|c|c|c|}
\hline \multirow{2}{*}{$\begin{array}{l}\text { Time } \\
\text { (hours) }\end{array}$} & \multicolumn{3}{|c|}{ Temperature $\left({ }^{\circ} \mathrm{C}\right)$} & \multirow{2}{*}{$\begin{array}{l}\text { Heart rate } \\
\text { (per minute) }\end{array}$} & \multirow{2}{*}{$\begin{array}{l}\text { Respiratory } \\
\text { rate } \\
\text { (per minute) }\end{array}$} & \multirow[t]{2}{*}{ Comments } & \multirow{2}{*}{$\begin{array}{l}\text { Basal metabolic rate } \\
\left(\mathrm{KJ} / \mathrm{m}^{2} \text { per hour }\right)\end{array}$} \\
\hline & Room & Skin & Oral & & & & \\
\hline 0930 & 23 & 29 & $32 \cdot 8$ & 53 & 13 & & 352 \\
\hline 1000 & 26 & 30.6 & 33 & 55 & 14 & & \\
\hline 1030 & 31 & $32 \cdot 9$ & $33 \cdot 2$ & 52 & 13 & Feels uncomfortable & \\
\hline 1100 & 34 & 34 & $33 \cdot 4$ & 63 & 10 & & \\
\hline 1130 & $35 \cdot 5$ & $34 \cdot 3$ & 34 & 66 & 13 & & \\
\hline 1200 & 40 & $35 \cdot 7$ & $34 \cdot 9$ & 70 & 12 & Feels uncomfortable & \\
\hline 1230 & 41 & 36 & $35 \cdot 2$ & 78 & 11 & & \\
\hline 1300 & 47 & $36 \cdot 4$ & $36 \cdot 6$ & 87 & 12 & & \\
\hline 1325 & 43 & $36 \cdot 7$ & 37 & 102 & 13 & Sweating, very uncomfortable & \\
\hline 1345 & 42 & 37 & $37 \cdot 3$ & 108 & 12 & & 383 \\
\hline
\end{tabular}

\section{Discussion}

The cause of this boy's hypothermia remains unknown. His temperature-regulating mechanism appears to be set at a lower level than is normal but he responds appropriately although in an exaggerated manner when his temperature is altered from its usual low level. In normal people a drop in central temperature below $36^{\circ} \mathrm{C}$ will cause shivering, even in the absence of stimuli from cold skin, ${ }^{6}$ but in this patient shivering occurred at a much lower $\left(33 \cdot 2^{\circ} \mathrm{C}\right)$ temperature.

Hypothalamic and central nervous system dysfunction is a known cause of hypothermia. ${ }^{245}$ In this patient computerised tomography scans of the head failed to show a lesion affecting the hypothalamus. The insulin hypoglycaemia test is the best test for assessing the functional adequacy of the hypothalamic-pituitary adrenal axis, ${ }^{78}$ and in this patient the results of the insulin tolerance test suggested hypothalamic dysfunction. There was no evidence of syphilis, tuberculosis, sarcoidosis, or a slow virus infestion-such as kuru or scrapie. The most likely cause of this boy's hypothermia is a very small lesion of the anterior hypothalamus which is not yet detectable on computerised tomography scanning.

The patient and his family have been advised to ensure that he has adequate insulation especially of the extremities to prevent heat loss, particularly in cold weather. He will be followed up closely as an outpatient.

We thank Professor Edwards, University College Hospital, and Mr B Hockley, Middlesex Hospital, for performing the studies of mitochondria and BMR respectively.

\section{References}

1 Royal College of Physicians of London. Report of the Committee on Accidental Hypothermia. London: Royal College of Physicians, 1966.

2 Bauer H G. Endocrine and other clinical manifestations of hypothalamic disease. J Clin Endocrinol Metab 1954; 14: 13-31.

3 Hockaday T D R, Cranston W I, Cooper K E, Mottram R F. Temperature regulation in chronic hypothermia. Lancet 1962 ; ii : 428-32.

4 Fox R H, Davies T W, Marsh F P, Urich H. Hypothermia in a young man with an anterior hypothalamic lesion. Lancet 1970; ii: 185-8.

5 Bannister R G. Classification and causes of heat illness. Thesis, Oxford 1963: 175-84.

6 Johnson R M, Spalding J M K. The role of a central temperature receptor in shivering in man. $J$ Physiol (Lond) 1966; 184: 733-40.

7 Jacobs H S, Nabarro J D. Tests of hypothalamicpituitary-adrenal function in man. $Q J$ Med 1969; 38: 475-91.

8 Anonymous. Testing the hypothalamic-pituitary-adrenal axis. $\mathrm{Br}$ Med J 1970; i: 644.

Correspondence to Dr C G D Brook, Middlesex Hospital, Mortimer Street, London W1N 8AA.

Received 7 October 1982 